\title{
Fælles udenrigstjeneste med fødselsvanskeligheder
}

\section{Poul Skytte Christoffersen}

EU's udenrigstjeneste under Ashton har fortrængt formandskabet i udenrigs- og sikkerhedspolitik, men kritiseres for ikke at være nok i spil selv. Det danske formandskab vil forsøge at skabe større systematik i samarbejdet med Ashton

Catherine Ashton tiltrådte som EU's første høje repræsentant (HR) for udenrigsanliggender og sikkerhedspolitik 11 dage efter at hun - til manges og ikke mindst sin egen overraskelse - var blevet udnævnt til stillingen af Det Europæiske Råd.

HR har ansvar for

- at udvikle og gennemføre den fælles udenrigs- og sikkerhedspolitik inklusive forsvarspolitik (dvs. videreføre det fuldtidsjob, som Javier Solana siden Amsterdam-traktaten havde udført for Rådet).

- de eksterne 'fællesskabspolitikker' som vicepræsident i Kommissionen havde haft.

- koordinering af alle aspekter af EU's eksterne aktioner, inklusive de eksterne aspekter af EU's interne politikker (ny opgave) og
- at lede arbejdet i Rådet af udenrigsministre som fast formand.

Lissabon-traktaten havde således lagt 3-4 heldagsjob sammen i den ny stilling som HR, og uden at forudse stedfortrædere.

For at få systemet til at fungere var det afgørende hurtigt at få skabt et fælles administrativt system (FUT'en) til at betjene Catherine Ashton. En af hendes første opgaver var derfor at etablere FUT'en - næsten fra 'scratch' pga. meget mangelfuld forberedelse.

Samtidig med at Rådet i efteråret 2009 var gået i gang med sit forberedende arbejde, havde Europa-Parlamentet (EP) forberedt sig og var fast besluttet på at anvende sine beføjelser under traktaten til at øve indflydelse på FUT’ens etablering. På cen- 
trale punkter havde Parlamentet holdninger, der stred mod Rådets; fx forkastede EP, at tjenesten skulle være autonom i forhold til Kommissionen. Grundlæggende ønskede Parlamentet, at FUT'en blev et normalt generaldirektorat i Kommissionen. For Rådet var dette uacceptabelt.

FUT'en skulle også have ansvar for EU's sikkerheds- og forsvarspolitik og kunne derfor ikke lægges ind under Kommissionen.

Kommissionen var heller ikke nogen let medspiller. Der var uenighed i fx grænsedragningen for udviklings- og naboskabspolitik. Et andet konfliktområde var delegationerne $\mathrm{i}$ udlandet. Ifølge Lissabon-traktaten skulle Kommissionens delegationer i tredjelande omdannes til EU-delegationer under HR og FUT'en.

Der var således udsigt til langvarige inter-institutionelle slagsmål i forbindelse med FUT'ens etablering. På denne baggrund var det lidt af et mirakel, at alle vanskeligheder blev overvundet på mindre end et år: - Den 25. marts fremlagde HR sit forslag til basisafgørelsen for FUT'en. - En måned senere vedtog Rådet sin politiske holdning til basisafgørelsen. Herefter førte et intenst forhandlingsforløb med Parlamentet, frem til enighed mellem HR, Kommission, Råd og Parlament i begyndelsen af juli. Den 26. juli vedtog Rådet den formelle afgørelse - I løbet af de første efterårsmåneder kom personalevedtægt, finans- forordning og budget på plads.

Allerede i forarbejdet udført under svensk formandskab var der etableret enighed om, at FUT'en skulle dække alle aspekter af EU's udenrigs- og sikkerhedspolitik. Det betød blandt andet, at EU's militære stab (omkring 200 officerer fra medlemslandene) og alt stab i civil- og militær krisestyring skulle overføres til FUT'en.

\section{FUT'ens områder}

Der var større vanskeligheder med at trække skillelinjen mellem FUT'en og Kommissionen med hensyn til andre aspekter af EU's eksterne anliggender som den fælles handelspolitik, udviklingssamarbejde, andet $\varnothing$ konomisk og finansielt samarbejde med tredjelande og humanitær bistand.

Sagen var ikke blevet lettere af, at Manul Barroso i sin nye Kommission - ud over en kommissær for den fælles handelspolitik (Karel De Gucht) - havde udnævnt en kommissær med ansvar for udvidelsesog naboskabspolitik (Stefan Füle), en kommissær med ansvar for udviklingspolitik i AVS-landene(Andris Piebalgs), og en kommissær med ansvar for internationalt samarbejde, humanitær bistand og krisestyring (Kristalina Georgieva). Dette skabte usikkerhed om HR og FUT'ens arbejdsområde. De reelle problemer var især knyttet til udviklingspolitikken og naboskabspolitikken. Der var 
generel enighed i institutionerne om, at handelspolitik skulle forblive en selvstændig portefølje under et generaldirektorat i Kommissionen. Det samme var tilfældet med humanitær bistand (herunder katastrofebistand). På disse områder blev HR og FUT'ens kompetence begrænset til at sikre koordinering, jf. HR's ansvar for at koordinere alle aspekter af EU's eksterne anliggender.

Tilbage stod en principiel debat om graden af politisk styring af udviklingspolitikken i spørgsmålet om arbejdsfordelingen mellem FUT'en og Kommissionens Generaldirektorat for Udvikling. En række medlemslande og dele af Kommissionen insisterede på, at udviklingspolitikken forblev under udviklingskommissæren, uden politisk indblanding fra HR og FUT'en, hvilket kunne skabe tvivl om EU's udviklingspolitiks fattigdomsorientering.

Efter FUT'ens etablering skulle der kun eksistere kontorer med ansvar for enkelte tredjelande i udenrigstjenesten, og ikke længere parallelle landekontorer i Kommissionens generaldirektorater eller i Rådet. Det var således klart, at FUT'en $i$ et vist omfang måtte inddrages i EU's udviklingsbistand. Efter vanskelige forhandlinger mellem HR og hendes kommissionskollegaer blev der enighed om, at FUT'en skulle være ansvarlig for de mest politiske aspekter af programmering af EU's udviklingspolitik. Prisen var, at udviklingskommissæren fik ansvar for
FUT'ens arbejde med programmeringen, og at alle formelle forslag til Kommissionskollegiet - der havde det sidste ord, inden forslaget gik til Råd og EP, blev fremlagt under HR og udviklingskommissærens fælles ansvar. Samme arbejdsfordeling blev aftalt mellem HR og Kommissæren for udvidelses- og naboskabspolitik for så vidt angår støtte til EU's nabolande.

Alt i alt kan det konstateres, at den FUT, der blev etableret, har et betydeligt bredere spektrum af instrumenter til sin rådighed end et normalt udenrigsministerium i et medlemsland (der fx ikke har enheder, der håndterer civil og militær krisestyring). FUT'en har ligeledes rådighed over eller er involveret $\mathrm{i}$ forvaltningen af betydeligt større pengebeløb i ekstern bistand (årligt mere end 10 mia. euro) end tilfældet er for nationale udenrigsministerier. EU er blevet verdens største enkeltdonor af udviklingshjælp.

\section{Personalepolitik}

Traktaten fastlægger, at FUT'en omfatter tjenestemænd fra 'relevante tjenestegrene i Generalsekretariatet for Rådet og Kommissionen samt udstationeret personale fra medlemsstaternes diplomatiske tjenester'. Den tager ikke stilling til fordelingen mellem de tre kilder til rekruttering. Tidligt i forberedelsesfasen opererede man med en tredjedel fra hver. Det stod imidlertid tid- 
ligt klart, at en permanent kvote på en tredjedel til Rådssekretariatet ikke gav mening. Ved FUT'ens etablering ville alt personale i Rådssekretariatet med kendskab til eksterne forhold blive overført til FUT'en, og der ville ikke være noget rekrutteringsgrundlag i fremtiden. Institutionerne enedes om, at mindst en tredjedel af personalet skulle komme fra medlemsstaterne og mindst 60 pct. fra institutionerne. 60-procent grænsen blev indført efter krav fra EP, for at hindre at tjenesten langsomt blev overtaget af personale fra medlemsstaterne.

Der udspandt sig en længere debat om, hvor mange år en diplomat, der kom fra et medlemsland, kunne tjene i FUT'en. Medlemslandene ønskede generelt en forholdsvis begrænset periode for at sikre, at deres diplomater ikke blev hængende $\mathrm{i}$ EU, men vendte tilbage med erfaringerne fra FUT'en. EP havde den modsatte holdning ud fra argumentet, at en kort udsendelsesperiode risikerede at medføre, at diplomaterne forblev primært loyale over for de nationale tjenester. Kompromiset blev en periode på 4 år med mulighed for forlængelse.

Der var generel enighed om, at udsendt personale fra medlemslande skulle have samme ansættelsesvilkår som fast personale.

Ansvaret for rekruttering blev pålagt HR, assisteret af hendes tjenestegrene, der træffer beslutning om hvilke kandidater, der skal udvælges blandt de diplomater, der bliver tilbudt fra medlemsstaterne. Medlemslandene har en vis indsigt $\mathrm{i}$ ansættelsesprocedurernes forløb gennem etableringen af et 'konsultativt udvalg for ansættelse' med 2 repræsentanter for FUT, Rådssekretariat, Kommission og medlemslande; men i sidste ende er det HR, der beslutter.

Ved FUT'ens start 1. januar 2011 blev der overført 1124 fra Kommissionen og 411 fra Rådssekretariatet. Staben forøges efter den foreløbige plan frem til 2013 med i alt 350 akademikere.

Sammenlignet med de fleste nationale udenrigsministerier er FUT'en en lille tjeneste. Den er større end den danske udenrigstjeneste (med ca. 450 akademikere) men mindre end den hollandske. De store medlemslandes diplomatiske stab tælles i tusinder.

\section{EU-delegationerne}

Traktaten fastlægger, at de tidligere kommissionsdelegationer omdannes til EU-delegationer. I modsætning til kommissionsdelegationerne, der kun dækkede spørgsmål under Kommissionens kompetence, skulle de nye EU-delegationer dække alle EU-spørgsmål, herunder EU's udenrigs- og sikkerhedspolitik, hvor det roterende formandskab (gennem deres ambassader) hidtil havde repræsenteret EU. Delegationerne skulle placeres under HR's autoritet. 
Kommissionens delegationer havde efterhånden opnået diplomatisk status i stort set alle tredjelande. Ved traktatens ikrafttræden blev tredjelande informeret om delegationernes nye status, herunder at delegationer snarest ville overtage den rolle, som tidligere var blevet udført af formandskabet. Ud over at repræsentere EU i udenrigs- og sikkerhedspolitik havde formandslandet også stået for koordination mellem de lokale ambassader i EU-anliggender og generelt repræsenteret EU over for de lokale myndigheder.

Omdannelsen til EU-delegationer skete gradvist i løbet af 2010. For de bilaterale EU-ambassaders vedkommende skete dette uden de store problemer. De største vanskeligheder opstod mellem Kommissionen og FUT'en, da spørgsmål om instruktionsbeføjelser og udnævnelsesprocedure for delegationscheferne skulle afklares. Kommissionen ønskede fortsat at kunne instruere deres medarbejdere i delegationerne uden indsigt fra FUT'ens side, ligesom den krævede medbestemmelsesret ved udnævnelse af delegationschefer. Det første slagsmål tabte Kommissionen.

Med hensyn til udnævnelse af delegationschefer blev det endelige resultat, at Kommissionen kan rette begrundede indsigelse mod en kandidat til delegationschef, der optræder på den 'short list', som er grundlaget for HR's endelige beslutning.

Der var i forhandlingsfasen stor uenighed mellem medlemslande om delegationernes kompetence vedrørende konsulære spørgsmål. Resultatet blev en meget svag tekst i basisafgørelsen: "Unionsdelegationerne støtter ....efter anmodning fra medlemsstaterne disse i deres diplomatiske forbindelser og i deres konsulære beskyttelse af unionsborgere i tredjelande på et ressourceneutralt grundlag."

Det blev således klart, at EU-delegationerne kun skulle have en subsidiær rolle i forhold til medlemsstaterne. Dette er uden tvivl et spørgsmål, der vil komme op igen ved fremtidige revisioner af FUT'ens rolle. For eksempel er det fortsat medlemslandene under ledelse af formandskabet, der er ansvarlig for kriseoperationer og evakuering af EUstatsborgere, ligesom udstedelse af Schengen-visa fortsat totalt ligger i medlemslandsregi. På begge områder forekommer en stærkere rolle for EU-repræsentationerne i fremtiden at være naturlig.

\section{De multinationale}

Situationen var betydeligt mere kompliceret for EU's repræsentation i multilaterale organisationer, hvor EU's status varierer fra fuldt medlemskab (FAO og WTO), over observatør (FN og de fleste andre internationale organisationer) til ingen status (Verdensbanken). En gennemførelse af traktatens intentioner om fælles EU-optræden ud- 
adtil krævede en ændring i denne situation. Det blev besluttet at starte med FN's generalforsamling, hvor EU var observatør, og EU's repræsentant således først kunne tage ordet, efter at alle FN's medlemslande (192) havde talt, og ikke havde mulighed for at fremlægge egne forslag.

I september 2010 fremlagde det belgiske formandskab på EU-landenes vegne et forslag i generalforsamlingen om en ændring i EU's status med henblik på at gøre det muligt for EU-repræsentanten at intervenere i debatten på et passende (tidligt) tidspunkt og at fremlægge forslag til beslutninger. Disse beskedne ønsker blev nedstemt. I maj 2011 blev fors $\varnothing-$ get gentaget, og denne gang med succes, men i noget udvandet form.

De fleste medlemslande var indstillet på at lade EU-delegationerne til de internationale organisationer stå for koordineringen af EU's holdning i alle spørgsmål. Efter tiltrædelsen af den nye britiske regering $i$ 2010 modsatte den sig EU-delegationen som fælles talsmand i spørgsmål med blandet kompetence. Det betyder, at EU i en række spørgsmål fortsat repræsenteres af det roterende formandskab, i modstrid med ambitionerne bag Lissabon-traktaten om, at EU i så vidt omfang som muligt taler med en stemme, der ikke skifter hver 6 måned.

Spørgsmålet om EU's repræsentation udadtil er derfor fortsat et uafklaret spørgsmål.

\section{Europa-Parlamentets rolle}

Europa-Parlamentet kom ikke igennem med dets to vigtigste krav: 1) At FUT'en skulle placeres i Kommissionen og 2) Udnævnelse af politiske stedfortrædere for HR, som EP ønskede tre af, svarende til de tre største partigrupper i Parlamentet. De politiske stedfortrædere blev afvist af Rådet af institutionelle og politiske grunde. Rådet ønskede ikke en yderligere politisering af FUT'en. Man var dog ikke blind for, at det i praksis kunne være vanskeligt for HR at overkomme alle de forpligtigelser, hun var blevet pålagt, herunder at deltage i debatter i EP. Der blev opnået enighed om, at en Kommissær kan dække en parlamentsdebat om sager, der både havde fællesskabsaspekter og udenrigspolitiske aspekter (det store flertal af parlamentsdebatter). Hvor debatten overvejende drejede sig om udenrigs- eller sikkerhedspolitiske spørgsmål, skulle udenrigsministeren eller en statssekretær fra det roterende formandskab eller et andet land i trioformandskabet træde til.

Herudover opnåede EP fremskridt med hensyn til politisk indsigt i FUT'ens funktion. HR afgav en erklæring om 'Political Accountability' vis-a-vis $\mathrm{EP}$, der omhandlede:

- Konsultation af EP om civile krisestyringsaktioner. Tidligere havde Parlamentet gennem sine budgetbeføjelser opnået at blive holdt regelmæssigt underrettet om denne type 
aktioner. Der var imidlertid tale om 'ex post' information. EP ønskede nu en formel konsultationsbeføjelse 'ex ante', dvs. inden beslutningen om iværksættelse af en aktion blev taget. EP vandt på substansen, idet HR indvilgede $i$ at have en meningsudveksling med EP inden aktioners iværksættelse, men EP kan ikke blokere iværksættelsen af en aktion.

- Høring af kandidater til topstillinger. EP's ambition var at kopiere det amerikanske system med senatshøringer af kandidater til ambassadørstillinger, inden de udnævnes, men medlemslandene var ikke indstillet på at importere 'amerikanske tilstande'. HR indvilgede dog i at svare positivt på anmodninger fra $\mathrm{EP}$, om at delegationschefer til lande og internationale organisationer, som EP fandt af strategisk betydning, kunne indkaldes til en meningsudveksling med EP, efter at delegationschefen var blevet udnævnt, men inden han tiltrådte.

\section{De første erfaringer}

Catherine Ashton fastlagde den 1. december 2010 som dagen, hvor FUT'en skulle træde i funktion. Den reelle ikrafttræden var snarere den 1. januar 2011, hvor personalet fra Kommission og Rådssekretariat blev overført til FUT'en. Fra samme dato overtog FUT'en formandskabet i den politiske- og sikkerhedspolitiske komite (PSC) og de underliggende arbejdsgrupper. Det roterende for- mandskabs rolle i EU's udenrigs- og sikkerhedspolitik var dermed stort set udspillet og overtaget af HR og FUT'en.

Siden Lissabon-traktatens ikrafttræden har der fra mange sider været luftet kritik af langsommelighed i etableringen af FUT'en og frustration over manglende resultater.

Denne kritik er delvist baseret på overdrevne forventninger.

Det var imidlertid et reelt problem, at de mere praktiske aspekter af FUT'ens funktion har taget længere tid at få på plads end forudset. Der var således store forsinkelser i etableringen af et organigram for FUT'en, og selv i dag er der fortsat uklarhed over samspillet mellem de forskellige enheder i FUT'en. Det har heller ikke hjulpet, at tjenesten endnu ikke er samlet, men er spredt ud over 6 bygninger i Bruxelles. Det administrative rod har kompliceret opgaven - der i forvejen ikke var let - med at sammensmelte de tre-fire kulturer, som er repræsenteret i FUT'en.

I kritikken af de manglende resultater er der som næunt også et element af overdrevne forventninger. Det må ikke glemmes, at samarbejdet i EU om udenrigs- og sikkerhedspolitik fortsat er baseret på klassisk mellemstatsligt samarbejde i modsætning til samarbejdet om andre EU-politikker. Hertil kommer, at der i udenrigs- og sikkerhedspolitikken eksisterer bremser for en tilbagerulning i samarbejdet i modsæt- 
ning til de øvrige samarbejdsområder inden for EU. En lang række af EU's politikker er karakteriseret af blandet kompetence mellem EU og dets medlemslande. Når der er vedtaget lovgivning om et spørgsmål inden for et sådant politikområde, overgår ikke kun den interne kompetence til EU, men også den eksterne kompetence. Medlemsstaterne kan kun genvinde kompetencen, hvis der fremlægges et forslag om en renationalisering fra Kommissionen, og forslaget vedtages af Råd og Parlament. Sandsynligheden for at dette sker, er ikke stor.

\section{Succeshistorier}

Kontrasten mellem arbejdsvilkår på et fællesskabsområde og i udenrigsog sikkerhedspolitikken var særligt slående for Ashton, der gik fra at være handelskommissær til rollen som HR. Med mindre Kommissionen stiller forslag og Rådet træffer beslutning, kan EU ikke agere på det handelspolitiske område. Men ej heller kan medlemslandene. Risikoen for et tomrum er en stærk impuls til at blive enige. Den samme mekanisme fungerer ikke på udenrigs- og sikkerhedspolitikken. Kan man ikke blive enige i EU, er konsekvensen ikke et tomrum, men 27 nationale politikker.

Catherine Ashton overtog lige efter sin tiltrædelse rollen som fast formand for Udenrigsministerrådet. Hun har vist sig at være en effektiv mødeleder og vist, at 'professionaliseringen' af formandsrollen kan bidrage til et mere resultatorienteret mødeforløb. Der er også skabt større kontinuitet i Rådets arbejde.

Men det er ikke altid let for en udenrigsminister - ofte med kort varsel - at træde til som stedfortræder for HR, når hun ikke selv kan være til stede. Det danske formandskab vil forsøge at skabe større systematik og forudsigelighed i samarbejdet mellem HR og udenrigsministeren i formandslandet.

Ligeledes har overgangen til fast formandskab i PSC og i arbejdsgrupperne på det eksterne område generelt fungeret godt med større kontinuitet og professionalisme. De faste formænd har generelt forstået at videreføre de gode elementer fra det hidtidige system, herunder ikke mindst at være lydhør over for input fra medlemslandene, og at yde den tilstrækkelige indsats for at forene medlemslandenes synspunkter. At dette system fungerer er ganske afgørende. Det er gennem indspil i arbejdsgrupper, komiteer og råd at medlemslandene kan øve indflydelse på udformningen af EU's udenrigspolitik. National indflydelse gennem disse kanaler er af større betydning end at sikre sig stillinger for egne diplomater i FUT'en.

Catherine Ashton har brugt megen tid på rejser bl.a. for at opbygge et solidt kontaktnet med de vigtige internationale spillere. Dette har båret frugt, og hverken USA's, Rus- 
lands eller Kinas udenrigsminister er længere i tvivl om nummeret på den europæiske udenrigsminister. Især forholdet til USA's udenrigsminister, Hillary Clinton, er tæt.

FUT'ens generalsekretær - franskmanden Pierre Vimont - kom fra stillingen som fransk ambassadør i Washington og har et bredt kontaktnet i både Bruxelles, medlemslandenes hovedstæder og i Washington.

Udfordringen er nu at anvende dette kontaktnet til at opbygge en forstærket global europæisk rolle. Det er lykkedes i den mellemøstlige fredsproces, hvor Catherine Ashton har placeret EU centralt i arbejdet i den såkaldte kontaktgruppe.

Der har været kamp med medlemslandenes udenrigsministre og især statsministre om at komme først i de internationale medier under vigtige udenrigspolitiske begivenheder. Derefter har de anklaget Ashton for at være for sent ude.

Den styrkede placering af EU-delegationerne rundt om i verden, som beskrevet ovenfor, bidrager til at styrke EU's effektivitet og synlighed. Der er grund til at tro, at EUambassadører efterhånden vil få en stærkere placering i deres opholdsland end ambassadører fra medlemslandene. De vil ikke i morgen 'overhale' de bilaterale ambassadører i Washington eller i Beijing. Men der vil sandsynligvis ikke gå lang tid, inden EU-ambassadøren i Pretoria, Brasilia, Jakarta, Mexico City eller i hovedstæderne hos andre af de nye internationale spillere (særligt i G20gruppen) vil få en stærkere rolle end kollegaer selv fra de store medlemslande, af den simple grund at EU-ambassadøren repræsenterer et langt bredere politikområde.

Men medlemslandenes ambassader har funktioner, som EU-ambassaderne i dag ikke kan dække, fx handelsfremme og konsulære opgaver. Under forudsætning af et velfungerende samarbejde mellem EUambassaden og medlemslandes ambassader kan især de små landes ambassader få stor glæde af EU's stærkere placering. I fremtiden kan det tænkes, at EU-ambassader kan tilskynde medlemslandene til at reducere ressourcekapaciteten i de pågældende lande.

At der stadig er arbejde tilbage med at skabe af en effektiv FUT er ingen overraskelse. På visse områder er hurtige fremskridt imidlertid påkrævet for at hindre, at FUT'en kører af sporet. At skabe fremskridt i EU-delegationernes funktion i internationale organisationer er et prioritetsområde. I det hele taget ligger der på bordet et stort og uafklaret problemkompleks omkring EU's internationale rolle og repræsentation, der rækker videre end HR og FUT'ens rolle.

Ud over disse spørgsmål er det min opfattelse, at tre problemkomplekser kræver særlig opmærksomhed: strategisk planlægning, forholdet til Kommissionen og sikkerhedspolitikken. 


\section{Strategisk planlægning}

En væsentlig ambition bag FUT'en var at bidrage til udviklingen af en mere gennemtænkt og sammenhængende strategi i EU's forhold til strategiske partnere, ikke mindst lande som USA, Kina, Indien, Brasilien, Rusland med flere.

EU har i mange år holdt regelmæssige topmøder med disse lande, men indholdet og resultaterne af møderne har (for at sige det diplomatisk) ikke altid været på højde med den strategiske betydning af landene. De har også været præget af skiftende formandskabers egne prioriteter i relation til de pågældende lande.

Med Lissabon-traktaten har de roterende formandskaber ikke længere ansvaret for disse møder. Det er nu formanden for Det Europæiske Råd, Van Rompuy, sammen med Kommissionsformanden, der repræsenterer EU. Det er FUT'ens rolle at levere input til disse møder. Indtil nu har man ikke kunnet konstatere nogen væsentlig forbedring, ligesom kvaliteten af det forarbejde som FUT'en har gjort til de drøftelser af EU's forhold til de strategiske partnere, der to gange har fundet sted i Det Europæiske Råd, ikke har været imponerende. Det skal tilføjes, at eurokrisen har gjort det vanskeligt for Rådet at give prioritet til disse drøftelser.

I det hele taget har FUT'en indtil nu været svag med hensyn til strate- gisk og langsigtet tænkning. Organisationsplanen forudser en planlægningsenhed, men indtil nu har den været svagt bemandet og ikke centralt placeret i tjenesten.

\section{Forholdet til Kommissionen}

FUT'en blev, som beskrevet ovenfor, skabt som en autonom enhed og ikke integreret i Kommissionen; men den blev ikke gjort til en selvstændig institution. Kun i forbindelse med sit administrationsbudget og personale skal FUT'en behandles som en institution. Fra starten var det imidlertid klart, at FUT'en ikke kun skulle beskæftige sig med klassisk udenrigs- og sikkerhedspolitik, men med hele EU's eksterne politik. Det var ikke kun Ashton, der skulle være 'dobbelthattet' med ansvar for både den mellemstatslige udenrigspolitik og de eksterne fællesskabspolitikker. Også FUT'en skulle have et ben i begge lejre.

Den bærende ide med FUT'en er at skabe sammenhæng i fællesskabets eksterne politik, så det er vigtigt, at der ikke graves grøfter mellem Kommission og FUT'en. Under alle omstændigheder skal spørgsmål, der falder under fællesskabskompetence (for eksempel økonomisk bistand til tredjelande), behandles efter fællesskabsmetoden, dvs. beslutninger eller forslag til beslutninger i Råd afgøres i kollegiet af kommissærer. Ideelt set bør FUT'en derfor fungere som et nor- 
malt generaldirektorat i Kommissionen, når tjenesten behandler fællesskabsanliggender.

Udviklingen i forholdet mellem FUT'en og Kommissionen har i den første tid ikke levet op til denne ambition. Ashton selv har haft tendens til at fokusere sin opmærksomhed på klassiske udenrigspolitiske spørgsmål og har ikke ofret megen energi på koordinering af alle aspekter af EU's eksterne politikker. Det har ikke lettet situationen, at det personale, der beskæftigede sig med disse ' globale udfordringer' ved BarrosoKommissionens dannelse blev overført til andre generaldirektorater i Kommissionen. Så der mangler ekspertise i FUT'en.

Desværre skubber mange i Kommissionen til en udvikling, der går i retning af en skarpere og foruroligende adskillelse mellem FUT'en og Kommissionen.

- Tidligere fandt der regelmæssige møder sted mellem de kommissærer, der var ansvarlige for politikområder med væsentlige eksterne aspekter. Siden Lissabon-traktatens ikrafttræden er denne praksis næsten ophørt (der har været afholdt tre møder - med Barroso og ikke Ashton i forsædet)

- Der er skabt en særlig enhed i Kommissionen for relationerne mellem Kommission og FUT'en. Udenrigstjenesten behandles, som var den en ekstern institution.

- Et betydeligt antal ansatte, der blev overført fra Kommissionen til
FUT'en søger nu tilbage til job i andre tjenestegrene i Kommissionen, så tjenestens ekspertise vedrørende fællesskabspolitikker reduceres. - Der er fortsat blandt mange kommissærer og deres tjenestegrene mangler forståelse for den nytte FUT'en - ikke mindst EU-delegationerne - kan have $i$ at indhente relevante informationer og sikre større forståelse rundt om i verden for, hvad EU står for.

Forhåbentligt er der tale om begyndervanskeligheder. Men stemmes der ikke op mod denne udvikling, vil der skabes store vanskeligheder for de helt centrale ambitioner med FUT'en, nemlig en kohærent og slagkraftig ekstern politik ved brug af EU's brede vifte af politikker, der har effekt udadtil.

\section{Sikkerhedspolitikken}

Sikkerheds- og forsvarspolitik har ikke stået højt på dagsordnerne efter Lissabon-traktatens ikrafttræden. Dette antyder et brud på den dynamiske udvikling, som disse områder havde i Javier Solanas tid.

Ikke mindst de civile krisestyringsoperationer ekspanderede i de år med det resultat, at EU har opbygget en kapacitet og en ekspertise, som overgår, hvad andre internationale aktører kan præstere.

EU opererer i dag store politi- og retsstatsmissioner (EULEX-Kosovo, EUPOL-Afghanistan, EUROJUSTIrak) og grænseovervågning (EUMM 
/Georgien og EUBAM/Gaza). Også på det militære område er EU operationel, fx til sikring af den indre sikkerhed i Bosnien (ALTHEA-Bosnien).

EU's civile og militære missioner komplementerer ofte hinanden og arbejder i symbiose med EU's andre politikker, fx på bistandsområdet. EU's nuværende flådeoperation i Det Indiske Ocean (ATALANTA) omkring piratbekæmpelse er et godt eksempel herpå. Flådeoperationen er kombineret med en anden militær aktion (EUTM-Somalia) til træning af somaliske sikkerhedsstyrker, humanitær bistand til Somalia og dets nabolande, samt aftaler med nabolande (især Kenya) om fængsling af tilbagetagne pirater.

Det er vigtigt, at dette ikke sættes overstyr, og at EU's kapacitet udbygges. Det mest presserende behov er at få opbygget et egentligt operationelt hovedkvarter for i hvert fald de civile operationer. For militære operationer kan EU trække på NATOhovedkvarterer eller på nationale operationscentre. Men dette er ikke muligt for civile operationer.

Et forslag fra HR om at påbegynde arbejdet med opbygningen inden for FUT'en af et operationelt hovedkvarter for civile- og militære operationer blev i juli 2011 blokeret i Rådet af Storbritannien.
For tyve år siden var der en debat, om EU med tiden skulle skabe sit eget forsvar, men ingen sætter i dag spørgsmålstegn ved, at NATO er ansvarlig for dette aspekt af forsvarspolitikken. Men EU kan ikke negligere de militære aspekter, hvis ambitionen er at blive en seriøs aktør internationalt. Libyen-krigen har vist, at Europa på afgørende felter mangler kapacitet til at gennemføre effektive operationer uden hjælp fra USA, men også at man ikke skal forvente, at USA automatisk træder til. Øget samarbejde mellem medlemslandene omkring våbenkøb og arbejdsfordeling mellem medlemslandene vil givet komme højere op på dagsordenen i de kommende år.

Det er vigtigt, at HR og FUT'en kan bidrage konstruktivt til, at der findes løsninger på disse udfordringer.

Poul Skytte Christoffersen, фkonom og diplomat. Forberedte udvidelsesforhandlingerne med 10 central- og østeuropaiske lande under det danske EU-formandskab $i$ 2002. Danmarks EU-ambassadør $i$ to omgange, nu sarlig rådgiver for Catherine Ashton. Artiklen bygger på et foredrag holdt på CBS i oktober.

(Forkortet af redaktionen). 